\title{
REPORT ON THE INTERNATIONAL ASSOCIATION OF LABOUR HISTORY INSTITUTIONS
}

Neither librarians nor archivists who work in the Labour Movement have so far had a chance to get together as a body of specialists. There was no provision for such a meeting at the professional international conferences, where political subjects are never discussed, and one found oneself at a disadvantage to know who was who. In any case, very few of us attend these conferences.

It was, as so often is the case, a chance meeting I had in Copenhagen that provided the initiative for us to move. On the basis of lists supplied by colleagues, the Socialist International and others, a preliminary conference was called in 1970 in London, and there the above organization was founded.

There were ten delegates from European countries present. They represented all branches of the Labour Movement: Socialists, Trade Unionists and cooperators-most of them librarians and archivists, but also those who produce information on the Labour Movement at universities and other institutions.

Initially it was felt that we, as practitioners in information in our field, ought to admit only our direct colleagues. Since then, historians and others who work in the field of Labour History have been admitted.

The main objectives of IALHI are to foster closer cooperation between member institutions, to issue bibliographies, holding lists and other information tools, and to encourage the exchange of material.

Our annual conference has become the forum for the exchange not only of material, but also for discussions of technical problems. The main concern of the conference is instructional. It is in fact geared to getting to know one another's Labour History and the relevant material available. Subjects discussed have ranged over a wide area: restoration and preservation of archival material, how to go about collecting it; computerization; up-to-date research into bibliographical services available; "Why Labour History"; the state of progress in Marxist research; the Internationals; and there is always a paper on the Labour History of the host country of the year. All conferences include visits to members' institutes and their libraries and to places of historical interest, e.g. Zimmerwald and Vienna Housing in the 1920s. A most important aspect of the conference is the personal contact with not only members of the association but also with people in the various institutes who attend the conference as guests. Information across national frontiers is easier once one knows the person one is dealing with face to face.

Another aspect of our work is to try and cooperate with other organizations which are of a similar character. The "Linz Standing Conference of Historians in the Labour Movement" is closely linked by membership. We also attended a conference in Mexico City where the proposal of a World Organization which would bring together mostly historians and sociologists was discussed. At the moment we are exploring ways in which we might cooperate on Labour History with the institutes in the socialist countries.

As to publishing: the association has published its directory to which each member contributes the relevant information on library and archive holdings, as well as other important data. This year the "Basic Reading List" has seen the light of day after three years of hard work by all of our 
members. This is a list of the basic books needed to get to know the Labour History of each member country. We have issued lists of second-hand booksellers, reputable publishers, and at the moment we are engaged in producing a directory of the Socialist Press. We have in mind also the production of a Thesaurus on Labour History terminology. All material we produce is circulated to all members and we hope that the major works will find their way into the national bibliographies.

As to the officers of the association: the secretary is elected for five years with a possible extension of another five years. The chairman for the duration of one year is elected at the annual conference and is always the host. Membership fee is $£ 5.00$ per annum and there is no charge to members attending the conference.

Irene Wagner (Mrs.),

Secretary, Librarian of the Labour Party

\section{REPORT ON THE SOUTHWEST LABOR STUDIES CONFERENCE}

The fourth annual Southwest Labor Studies Conference was held in Berkeley on March 17 and 18, 1978. Its sponsoring organization, the Southwest Labor Studies Association, was conceived as a bridge between labor activists-both union officials and members of the rank-and-file-and academics. At times the meeting in Berkeley fulfilled the promise of such an organization.

At its best the interaction between scholars and those who have provided the raw material for the scholars to work with should test interpretation against recalled experience. Yet all too often this sort of conference merely furnishes a forum where people who lack either the ability or the discipline to utilize more traditional forums have their hour of glory. Unfortunately good intentions are no substitute for hard work and thought. One deduces that some pecple think they are. Thus, the spectacle of a "scholar" who riffled through note cards and called this performance a paper or an activist who spent thirty minutes rapping about anything and everything in what was presumed to be a substantive presentation.

It is not necessary that activists have scholarly credentials in order to do creditable work for such occasions. Merely, they must take what they are doing seriously. In a generally excellent session on ethnic labor chaired by David Brody of U.C. Davis, two men with divergent experiences in the labor movement gave exemplary papers. Frank Arnold of the International Association of Machinists reviewed the life and work of Humberto Silex, a Nicaraguan who organized for the CIO in south Texas. Karl Yoneda recounted, in a largely autobiographical paper, the militancy of Japanese farm labor in California, especially in the 1930s. In addition, Michael Kazin, a graduate student at Stanford, analyzed the anti-Chinese riots in San Francisco in 1877.

Because of protests generated at earlier conferences, particular heed was given to the history of women and third world labor. Hence there was considerable emphasis on the experience of Chicano workers. An especially valuable paper came from Alex Saragosa of California State University, Fresno. Entitled, "Chicano Labor in the San Joaquin Valley: a Social History," it emphasized the diversity in the Chicano community and the resultant cultural conflict. 